\title{
Acute diquat poisoning with intracerebral bleeding
}

\author{
S A M Saeed, M F Wilks, M Coupe
}

\begin{abstract}
A case of severe diquat poisoning complicated by the development of aggressive behaviour, oliguric renal failure, and intracerebral bleeding is described. The patient was successfully managed and made a complete recovery. In this paper special attention has been given to the major clinical differences between diquat and paraquat intoxication.

(Postgrad Med F 2001;77:329-332)
\end{abstract}

Keywords: poisoning; diquat; paraquat

Diquat (1,1'-ethylene-2,2'- bipyridyldiylium) is a non-selective herbicide which belongs to the same class as the more widely used paraquat (1,1'-dimethyl-4,4' bipyridyldiylium) (fig 1$)$. In animal experiments the acute toxicity of diquat and paraquat is similar; however, there are far fewer case reports in the literature of diquat than of paraquat poisoning.

(A) Paraquat dichloride

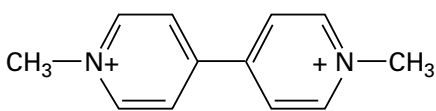

$2 \mathrm{Cl}^{-}$

(B) Diquat dibromide

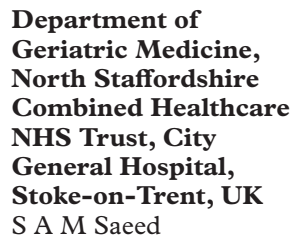

A Saeed

\section{Medical Toxicology \\ Unit, Guy's and \\ St Thomas' Hospitals \\ NHS Trust, London, \\ UK \\ M F Wilks}

Department of Medicine, Royal Oldham Hospital, Oldham, Greater Manchester, UK M Coupe

Correspondence to: Dr Saad A M Saeed, Springfield Unit, City General Hospital,

Stoke-on-Trent ST4 6QG, $\mathrm{UK}$

saad_saeed@hotmail.com

Submitted 18 May 2000 Accepted 22 August 2000

Figure 1 Structure of paraquat and diquat.

Table 1 Laboratory investigations (normal range in parentheses)
In previously described cases of fatal diquat intoxication, most of the patients died from complications involving the gastrointestinal tract, brain, and kidneys. As with paraquat, most of the fatalities involved ingestion of the concentrated formulation with suicidal intent.

\section{Case report}

A 52 year old white man, with a history of alcohol abuse, presented after the ingestion of about $160 \mathrm{ml}$ of "weed killer" with suicidal intent after his wife left him. The weed killer was thought to be paraquat solution at presentation but later a plain bottle was discovered with the words "Diquat Reglone Poison" written on it. Analysis by ultraviolet spectroscopy confirmed that it contained diquat ion at a concentration of 170 $\mathrm{g} / \mathrm{l}$. Ten minutes after ingestion, the patient began vomiting. On admission he was well orientated and not cyanotic. His vital signs were as follows: pulse rate 138 beats/min regular, blood pressure $130 / 87 \mathrm{~mm} \mathrm{Hg}$, respiratory rate 28 breaths $/ \mathrm{min}$, and arterial oxygen saturation on air of $91 \%$. Clinical examination was otherwise unremarkable. He was given $50 \mathrm{~g}$ of activated charcoal on arrival at the emergency department; this was followed by vomiting of brownish-blackish gastric contents. Activated charcoal was given four hourly as tolerated.

$\mathrm{He}$ was catheterised and started on intravenous fluids to maintain diuresis. An electrocardiogram and chest radiograph were initially normal. Initial laboratory investigations are shown in table 1.

His urine output in the first few hours after admission was $>100 \mathrm{ml} /$ hour with no detectable proteinuria or haematuria. Within a few hours his general condition deteriorated, he became drowsy, and his oxygen saturation fell to $88 \%$ on air. A qualitative urine test (dithionite test) which is normally used for

\begin{tabular}{|c|c|c|c|c|c|c|c|}
\hline & Day 1 & Day 2 & Day 3 & Day 10 & Day 23 & Day 33 & Day 47 \\
\hline Sodium $(136-145 \mathrm{mmol} / \mathrm{l})$ & 135 & 131 & 144 & 143 & 146 & 134 & 134 \\
\hline Potassium $(3.5-5 \mathrm{mmol} / \mathrm{l})$ & 3.3 & 3.1 & 3 & 3.1 & 4.1 & 3.8 & 3.7 \\
\hline Urea $(2.5-6.6 \mathrm{mmol} / \mathrm{l})$ & 4.4 & 7.4 & 29.4 & 42 & 32 & 43 & 10 \\
\hline Creatinine $(70-140 \mu \mathrm{mol} / \mathrm{l})$ & 157 & 261 & 710 & 970 & 674 & 314 & 131 \\
\hline Corrected calcium $(2.1-6.5 \mathrm{mmol} / \mathrm{l})$ & 2.3 & & 1.85 & 1.63 & 1.85 & 2.28 & 2.23 \\
\hline Phosphate $(0.70-1.4 \mathrm{mmol} / \mathrm{l})$ & 1.2 & & 2.15 & 1.62 & 1.42 & 2.08 & 1.14 \\
\hline Glucose $(2.5-10 \mathrm{mmol} / \mathrm{l})$ & 3.3 & & 11.4 & 9.5 & 5.6 & 6.6 & 9.1 \\
\hline Bicarbonate $(24-30 \mathrm{mmol} / \mathrm{l})$ & 17.4 & & 17.6 & 21 & 19 & & 19 \\
\hline Albumin $(33-49 \mathrm{~g} / 1)$ & 36 & & 31 & 28 & 31 & 36 & 27 \\
\hline Globulin $(21-38 \mathrm{~g} / \mathrm{l})$ & 42 & & 40 & 38 & 31 & 40 & 45 \\
\hline Aspartate aminotransaminase $(10-40 \mathrm{U} / \mathrm{l})$ & 25 & & 314 & 94 & 43 & 32 & 18 \\
\hline Alanine aminotransaminase $(5-40 \mathrm{U} / 1)$ & 19 & & 657 & 377 & 367 & 29 & 22 \\
\hline Total bilirubin $(<17 \mu \mathrm{mol} / \mathrm{l})$ & 6 & & 5 & 4 & 4 & 3 & 4 \\
\hline Alkaline transferase $(25-115 \mathrm{U} / \mathrm{l})$ & 70 & & 56 & 60 & 200 & 122 & 101 \\
\hline \multicolumn{8}{|l|}{ Arterial blood gases (room air) } \\
\hline $\mathrm{pH}(7.35-7.45)$ & 7.33 & & 7.37 & 7.22 & 7.36 & & 7.38 \\
\hline Carbon dioxide pressure $(4.8-6 \mathrm{kPa})$ & 4.34 & & 5.9 & 4.5 & 5 & & 4.6 \\
\hline Oxygen pressure $(11-13 \mathrm{kPa})$ & 8.9 & & 6.7 & 7.9 & 10.7 & & 12 \\
\hline Oxygen saturation $(95 \%-98 \%)$ & 92 & & 78 & 84 & 90 & & 93 \\
\hline \multicolumn{8}{|l|}{ Full blood count } \\
\hline Haemoglobin $(130-180 \mathrm{~g} / \mathrm{l})$ & 134 & & 117 & 125 & 100 & 100 & 90 \\
\hline White cell count $\left(4-11 \times 10^{9} / 1\right)$ & 8.4 & & 10.1 & 11.4 & 6.9 & 6.2 & 8.2 \\
\hline Platelets $\left(150-400 \times 10^{9} / 1\right)$ & 135 & & 190 & 185 & 190 & 182 & 236 \\
\hline
\end{tabular}


paraquat was said to be positive, although the colour and intensity was not described. The next day his renal function deteriorated despite adequate fluid replacement therapy and urine output. He became agitated and started showing signs of alcohol withdrawal. He was given parenteral diazepam but absconded from the ward and could not be traced. He was readmitted on the third day after intoxication with symptoms of dry cough, shortness of breath, dysphagia for solids, and repeated vomiting. On examination at this stage there was evidence of buccal mucosal ulceration. Vital signs showed blood pressure 157/105 mm Hg, radial pulse 116 beats/min, and respiratory rate 32 breaths/min. Chest examination showed harsh vesicular breath sounds with scattered inspiratory crackles at the lower and middle zones bilaterally. Chest radiography showed ill defined bilateral basal changes of possible infection or aspiration pneumonitis. He developed oliguric renal failure and type 1 respiratory failure (table 1). A blood sample taken several days after the ingestion showed that diquat was not detectable (limit of detection 50 $\mathrm{ng} / \mathrm{ml}$ ). The patient was transferred to a renal unit for dialysis.

He was noted to have widespread burns to his oral mucosa and tongue and marked perianal excoriation thought to be due to the irritant effect of diquat being passed per rectum. His blood gases deteriorated with radiological evidence of diffuse shadowing in both lung fields. It was not possible to say how much of this was related to chemical pneumonitis and how much to secondary pneumonia

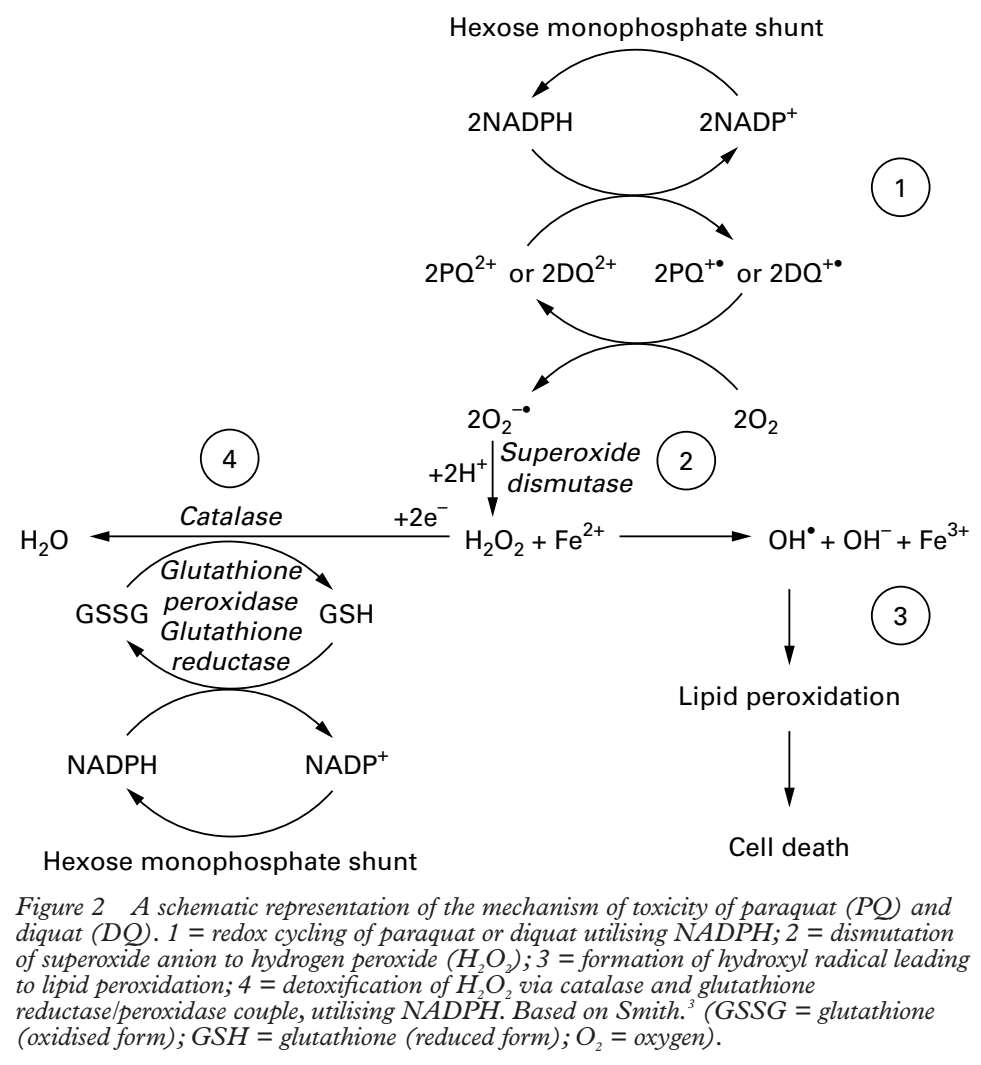

\section{Learning points}

- Despite having the same pathogenic mechanisms, cases of diquat and paraquat intoxication may have a different clinical course.

- The relative symptom-free interval after diquat ingestion, as in our patient, can last up to 48 hours and can give a false feeling of security. This should not be a reason for delay in initiation of treatment.

- Paraquat poisoning often induces severe lung damage leading to pulmonary fibrosis, which is usually fatal, while diquat causes mainly gastrointestinal and renal toxicity, sometimes complicated by intracranial haemorrhage or infarction.

induced by aspiration. He was treated conservatively with oxygen and antibiotics and he narrowly avoided ventilation.

His renal function continued to deteriorate and he required the institution of peritoneal dialysis for two weeks. During the acute illness he also developed drowsiness, dysphasia, and left hemiparesis. Computed tomography confirmed an intracerebral haematoma in the region of the right basal ganglia and external capsule. His renal function gradually improved and his chest signs cleared completely. $\mathrm{He}$ needed blood transfusion for anaemia. His stroke recovered gradually after a few months of physiotherapy.

A few months after the intoxication he was complaining of shortness of breath on exertion. Pulmonary function tests did not show any evidence of fibrotic lung sequelae. His shortness of breath was thought to be related to chronic bronchitis secondary to chronic heavy smoking.

\section{Discussion}

Paraquat and diquat are bipyridilium herbicides, which are inactivated by adsorption to clay material in the soil. ${ }^{1}$ The most widely available formulations for both chemicals (for example "Gramoxone" for paraquat and "Reglone" for diquat) are 20\% liquid concentrates for professional use only. Numerous paraquat/ diquat mixtures, as well as mixtures with other herbicides are available. A low strength granular formulation containing $2.5 \%$ paraquat and $2.5 \%$ diquat is sold in the UK and Ireland for home and garden use. The toxicity of the bipyridilium compounds is based on identical mechanisms and is very similar to the toxicity of oxygen. ${ }^{23}$ The main difference between paraquat and diquat is that the former is actively accumulated in the lung, while the latter is not. ${ }^{4}$

Intracellularly, both chemicals undergo redox cycling, leading to the generation of superoxide anions (fig 2 ). These may react to form hydrogen peroxide and subsequently the highly reactive hydroxyl radical which is thought to be responsible for lipid peroxidation and cell death. A second contributing factor to 
Table 2 Clinical features of paraquat and diquat poisoning

\begin{tabular}{|c|c|c|}
\hline & Paraquat* & Diquat \\
\hline Mild or subacute poisoning & $\begin{array}{l}\text { Ingested dose }<20-30 \mathrm{mg} / \mathrm{kg} \ddagger \\
\text { Asymptomatic or: } \\
\text { Mucosal irritation } \\
\text { Nausea and vomiting } \\
\text { Transient renal/hepatic function impairment } \\
\text { Transient decrease of diffusing capacity }\end{array}$ & $\begin{array}{l}\text { Ingested dose }<50 \mathrm{mg} / \mathrm{kg} \ddagger \\
\text { Asymptomatic or: } \\
\text { Mucosal irritation } \\
\text { Nausea and vomiting } \\
\text { Transient renal/hepatic function impairment } \\
\text { Transient decrease of diffusing capacity }\end{array}$ \\
\hline \multirow[t]{2}{*}{ Moderate to severe poisoning } & $\begin{array}{l}\text { Ingested dose }>20-30 \mathrm{mg} / \mathrm{kg} \text { but }<40-55 \mathrm{mg} / \mathrm{kg} \ddagger \\
\quad \text { Vomiting and diarrhoea }\end{array}$ & $\begin{array}{l}\text { Ingested dose }>50 \mathrm{mg} / \mathrm{kg} \text { but }<200 \mathrm{mg} / \mathrm{kg} \ddagger \\
\text { Vomiting and diarrhoea, often bloody (maybe } \\
\text { preceded by asymptomatic phase of up to } 48 \\
\text { hours }\end{array}$ \\
\hline & $\begin{array}{l}\text { Oropharyngeal ulceration } \\
\text { Acute renal and hepatic failure (after } 2-5 \text { days) } \\
\text { Decrease of diffusing capacity, } x \text { ray shows patchy lung infiltrations } \\
\text { Often progress to pulmonary fibrosis and refractory hypoxaemia } \\
\quad \text { (after } 5 \text { days to several weeks) }\end{array}$ & $\begin{array}{l}\text { Oropharyngeal ulceration } \\
\text { Intestinal fluid loss and paralysis } \\
\text { Hypovolaemic shock } \\
\text { Acute renal and hepatic failure (after } 2-5 \text { days) } \\
\text { Brain stem infarction and/or intracranial bleeding }\end{array}$ \\
\hline Fulminant or hyperacute poisoning & $\begin{array}{l}\text { Ingested dose }>40-55 \mathrm{mg} / \mathrm{kg} \ddagger \\
\text { Severe vomiting and diarrhoea } \\
\text { Gastrointestinal ulcerations } \\
\text { Renal and hepatic failure } \\
\text { Alveolitis and non-cardiogenic pulmonary oedema } \\
\text { Cardiac arrhythmias } \\
\text { Coma } \\
\text { Death within } 1-4 \text { days from multiorgan failure }\end{array}$ & $\begin{array}{l}\text { Ingested dose }>200 \mathrm{mg} / \mathrm{kg} \ddagger \\
\text { Severe vomiting and diarrhoea } \\
\text { Gastrointestinal ulcerations } \\
\text { Massive intestinal fluid loss } \\
\text { Renal and hepatic failure } \\
\text { Pulmonary oedema } \\
\text { Cardiac arrhythmias } \\
\text { Coma } \\
\text { Death within 1-2 days from multiorgan failure }\end{array}$ \\
\hline
\end{tabular}

All doses are estimates of bipyridyl ion.

${ }^{\star}$ Modified from references 5 and 6 .

†Based on references 7-20 and unpublished observations.

$¥$ These doses are estimates and should be used only for guidance.

toxicity is the depletion of nicotinamide adenine dinucleotide phosphate with bound hydrogen ion (NADPH), as both paraquat redox cycling as well as hydrogen peroxide detoxification via glutathione is NADPH dependent.

Since 1966 a large number of instances of intoxications with paraquat have been reported, mainly as a result of deliberate ingestion, while the number of reported diquat poisonings is comparatively small. For both chemicals the clinical course is entirely dependent on the amount ingested (table 2 ). In mild poisoning, as well as acute fulminant poisoning, the clinical picture is essentially the same for both bipyridyls. ${ }^{5-12}$ This is also the case for the initial phase in moderate to severe intoxication, which is characterised by reversible renal and liver failure. However, despite having the same pathogenic mechanisms, the subsequent clinical course of paraquat and diquat poisoning in this group is quite different. In paraquat poisoning, delayed development of pulmonary fibrosis is responsible for the generally poor prognosis. ${ }^{5}{ }^{6}$ In contrast, intestinal paralysis and fluid loss is a prominent feature of diquat intoxication and may lead to abdominal distension, tissue dehydration, and hypotensive shock. ${ }^{7-9} 1112$ Severe neurological and neuropsychiatric complications due to brain stem infarction and/or intracranial haemorrhage, as observed in our patient, have been described in the literature. ${ }^{81314}$ Pulmonary fibrosis has not been seen after diquat poisoning. ${ }^{7-14}$

The treatment of diquat intoxication is based on the same principles as described for paraquat poisoning with prevention of absorption and enhanced elimination being the mainstay of the therapy. Gastric lavage and the use of activated charcoal, Fuller's earth, or bentonite together with administration of a cathartic have been advocated as an early treatment to minimise absorption from the gastrointestinal tract..$^{8}$

Gastric and intestinal decontamination should be performed cautiously because of the risk of perforation, particularly when treatment is delayed. Adsorbent material should be instilled with care during intestinal paralysis since massive sequestration may occur.

Because of the massive fluid losses into the gastrointestinal tract and its potential circulatory and renal consequences, special attention must be given to adequate hydration of the patient, ideally with monitoring of central venous pressure. ${ }^{89}$ Anticoagulants should be administered with great caution because of the risk of brain stem haemorrhage. Forced diuresis has been used to enhance the elimination of diquat, ${ }^{15}$ however, there is no conclusive evidence of its therapeutic value.

Extracorporeal haemodialysis was found to be ineffective in removing diquat from the circulation. ${ }^{17}$ As with paraquat, haemoperfusion with activated charcoal has been suggested as a more effective way of lowering the plasma diquat concentration, but a beneficial effect has not been conclusively demonstrated. ${ }^{818-20}$ The mainstay of an adequate therapeutic approach for paraquat and diquat poisoning continues to be prompt treatment as soon as possible after ingestion.

We would like to thank Zeneca Central Toxicology Laboratory, Alderley Park, Macclesfield, United Kingdom for the analysis of blood and product samples. Dr Wilks acts as Medical Adviser to Zeneca Agrochemicals, manufacturers of paraquat and diquat containing products.

1 Conning DM, Fletcher K, Swann A. Paraquat and related bipyridyls. Br Med Bull 1969;25:245-9.

2 Clark DG, McElligot TF, Weston Hurst E. The toxicity of paraquat. Br f Ind Med 1966;23:123-6.

3 Smith LL. Mechanism of paraquat toxicity in the lung and its relevance to treatment. Hum Toxicol 1987;6:31-6.

4 Litchfield MH, Daniel JW, Longshaw S. The tissue Litchfield $\mathrm{MH}$, Daniel JW, Longshaw S. The tissue paraquat in rats and mice. Toxicology 1973;1:155-65. paraquat in rats and mice. Toxicology 1973;1:155-65.

Vale JA, Meredith TJ, Buckley BM. Paraquat poisoning: clinical features and immediate general management. Hum
Toxicol 1987;6:41-8. 
6 Bismuth C, Hall AH, Wong A. Paraquat ingestion: exposure symptomatology and risk. In: Bismuth $\mathrm{C}$, Hall $\mathrm{AH}$, eds Paraquat poisoning. New York: Marcel Dekker Inc, 1995: $195-210$

Okonek S. Vergiftungen durch Paraquat oder Deiquat. Die Medizinische Welt 1976;27:1401-5.

8 Vanholder R, Colardyn F, De Reuck J, et al. Diquat intoxication. Report of two cases and review of the literature. $A m$ f Med 1981;70:1267-71.

9 Jones GM, Vale JA. Mechanisms of toxicity, clinical features, and management of diquat poisoning: a review. $\mathcal{F}$ Toxicol Clin Toxicol 2000;38:123-8.

10 Fel P, Zala I, Szüle E, et al. Haemodialysisse gyogyitett diquat-dibromide (Reglone) mergezes. Orr Hetil 1976;117: 1773-4.

11 McCarthy LG, Speth CP. Diquat intoxication. Ann Emerg Med 1983; 12:394-6.

12 Schmidt DM, Neale J, Olson KR. Clinical course of a fatal ingestion of diquat. $\mathcal{F}$ Toxicol Clin Toxicol 1999;37:881-8.

13 Schönborn H, Schurter HP, Kössling FK. Klinik und Morphologie der akuten peroralen Diquat Intoxikation (Rephologie der akuten peroralen Diquat
glone). Arch Toxicol 1971;27:204-16.
14 Rudez J, Sepcic K, Sepcic J. Vaginally applied diquat intoxication. F Toxicol Clin Toxicol 1999;37:877-8.

15 Oreopoulos D G, McEvoy J. Diquat poisoning. Postgrad Med f 1969;45:635-7.

16 Mahieu P, Bonduelle Y, Bernard A, et al. Acute diquat intoxication interest of its repeated determination in urine and the evaluation of renal proximal tubule integrity. 7 Toxicol Clin Toxicol 1984;22:363-9.

17 Okonek S, Hofmann A. Extracorporeal haemodialysis in diquat intoxication. Arch Toxicol 1975;33:251-7.

18 Powell D, Pond SM, Allen TB, et al. Hemoperfusion in a child who ingested diquat and died from pontine infarction and haemorrhage. $\mathcal{F}$ Toxicol Clin Toxicol 1983:20: 405-20.

19 Williams PF, Jarvie DR, Whitehead AP. Diquat intoxication: treatment by charcoal haemoperfusion and description of a new method of diquat measurement in plasma. 7 Toxicol Clin Toxicol 1986;24:11-20.

20 Hantson P, Wallemacq P, Mahieu P. A case of fatal diquat poisoning: toxicokinetic data and autopsy findings. $\mathcal{f}$ Toxicol Clin Toxicol 2000;38:149-52.

\title{
Narrative Based Medicine, An Interdisciplinary Conference
}

\author{
Research, Narrative, and Practice
}

A two day conference-Monday 3rd and Tuesday 4th September 2001

\section{Homerton College, Cambridge, UK}

BMf Publishing Group

For full details contact: BMA/BMJ Conference Unit, Tavistock Square, London, WC1H 9JP Tel: +44 (0)207383 6819; fax: +44 (0)207383 6663; email: clyders@bma.org.uk.

www.quality.bmjpg.com 